\title{
Faktor Sosial Ekonomi yang Berhubungan dengan Permintaan Bawang Merah Di Kecamatan Amuntai Selatan Kabupaten Hulu Sungai Utara
}

\section{(Socio Economic Factors Associated with Onion Demand in District Amuntai Selatan Hulu Sungai Utara Regency)}

\author{
Arief Hidayatullah ${ }^{1)}$ \& Riswandi \\ Program Studi Agribisnis, Sekolah Tinggi Ilmu Pertanian Amuntai \\ 1)arief_stiperamuntai@yahoo.com
}

\begin{abstract}
ABSTRAK
Penelitian ini bertujuan (i) mengetahui besarnya permintaan bawang merah oleh rumah tangga di Kecamatan Amuntai Selatan, (ii) mengetahui besarnya pengeluaran untuk permintaan bawang merah oleh rumah tangga di Kecamatan Amuntai Selatan dan (iii) mengetahui pengaruh faktor sosial ekonomi terhadap besarnya permintaan bawang merah oleh rumah tangga di Kecamatan Amuntai Selatan. Penelitian ini dilakukan di enam desa di Kecamatan Amuntai Selatan, yaitu Kota Raja, Jumba, Murung Sari, Mamar, Teluk Paring dan Cempaka dengan menggunakan cluster random sampling multistage way. Berdasarkan hasil penelitian rata-rata permintaan bawang merah oleh rumah tangga sebesar 1,44 $\mathrm{kg} /$ bulan. Pengeluaran untuk permintaan bawang merah dalam sebulan sebesar Rp. 8.338,33 atau 0,52\% dari total pendapatan keluarga. Dari hasil analisis korelasi dan uji t terdapat hubungan yang signifikan antara tingkat permintaan bawang merah dengan jumlah anggota keluarga dan selera, sedangkan faktor pendapatan keluarga, harga bawang merah, tingkat pendidikan formal ibu rumah tangga, umur ibu rumah tangga dan daerah asal ibu rumah tangga tidak mempunyai hubungan yang signifikan terhadap permintaan bawang merah. Analisis jalur diperoleh, bahwa variabel total pendapatan keluarga, variabel harga bawang merah, variabel jumlah anggota keluarga, variabel tingkat pendidikan ibu rumah tangga, variabel umur ibu rumah tangga, variabel daerah asal ibu rumah tangga, dan variabel selera ibu rumah tangga berpengaruh total terhadap permintaan bawang merah.
\end{abstract}

Kata kunci: Permintaan bawang merah, faktor sosial ekonomi, analisis korelasi.

\section{ABSTRACT}

This study aims to (i) determine the magnitude of demand for shallots by households in Amuntai Selatan Subdistrict, (ii) find out the amount of expenditure for shallot demand by households in South Amuntai Subdistrict and (iii) to know the effect of socio-economic factors on the demand by households in the Amuntai Selatan District. This research was carried out in six villages in Amuntai Selatan District, namely Kota Raja, Jumba, Murung Sari, Mamar, Paring Bay and Cempaka using cluster random sampling multistage way. Based on the results of the study, the average demand for shallots by households is $1.44 \mathrm{~kg}$ / month. Expenditures for demand for shallots in a month is Rp. 8,338.33 or 0.52\% of total family income. From the results of correlation analysis and t-test there is a significant relationship between the level of demand for shallots with the number of family members and tastes, while family income factors, prices of shallots, formal education level of housewives, age of housewives and areas of origin of housewives are not has a significant relationship to the demand for shallots. Path analysis was obtained, that variable was total family income, variable price of shallots, variable number of family members, variable level of education of housewives, variable age of housewives, regional variables of origin of housewives, and variable tastes of housewives had a total effect on demand Red onion.

Keywords: Onion demand, socioeconoomic factors, correlation analysis.

\section{PENDAHULUAN}

\section{Latar Belakang Masalah}

Bawang merah merupakan komoditi hortikultura yang tergolong sayuran rempah. Cerahnya prospek bawang merah juga didukung oleh tidak adanya bahan pengganti, baik yang sintetis maupun alami (Rahayu \& Nur, 2004). Harga bawang merah selalu berfluktuasi, banyaknya kegunaan bawang merah dalam kehidupan manusia menyebabkan permintaan terhadap 
Rawa Sains: Jurnal Sains STIPER Amuntai, Desember 2011, 1(1), 24-29.

komoditas ini semakin bertambah sehingga pasarnya tetap terbuka luas, baik pasaran dalam negeri maupun ekspor (Samadi \& Bambang, 2005).

Bawang merah yang dipasarkan di Pasar Amuntai tidak hanya berasal dari Pasar Amuntai sendiri, namun juga berasal dari pasar-pasar kecil lain yang ada di Kabupaten Hulu Sungai Utara. Karena dari pasar-pasar itulah yang dapat menutupi tingginya tingkat konsumsi bawang merah di Kabupaten Hulu Sungai Utara. Permintaan bawang merah di Pasar Amuntai pada tahun 2009 mencapai 4 ton.

Faktor sosial ekonomi ber-hubungan dengan permintaan bawang merah. Faktor sosial ekonomi di Kabupaten Hulu Sungai Utara terutama di Kecamatan Amuntai Selatan terhadap tingkat permintaan bawang merah rumah tangga yaitu pendapatan, harga, jumlah anggota keluarga, pendidikan, umur, asal daerah dan selera. Sehingga perlu adanya penelitian mengenai pengaruh faktor sosioekonomi terhadap besarnya tingkat permintaan bawang merah di kecamatan tersebut.

Tujuan Penelitian ini adalah (1) Mengetahui besarnya permintaan bawang merah oleh rumah tangga di Kecamatan Amuntai Selatan. (2) Mengetahui besarnya pengeluaran untuk permintaan bawang merah oleh rumah tangga di Kecamatan Amuntai Selatan. (3) Mengetahui pengaruh faktor sosial ekonomi terhadap besarnya permintaan bawang merah oleh rumah tangga di Kecamatan Amuntai Selatan.

\section{METODE PENELITIAN}

\section{Tempat dan Waktu Penelitian}

Penelitian ini dilaksanakan pada bulan Maret - Juni 2010. Lokasi penelitian di Kecamatan Amuntai Selatan Kabupaten Hulu Sungai Utara yakni di desa Kota Raja, Jumba, Murung Sari, Mamar, Teluk Paring dan Cempaka.

\section{Jenis dan Sumber Data}

Data primer diperoleh dari hasil wawancara langsung dan dari pengisian daftar pertanyaan yang diberikan kepada responden (ibu rumah tangga) yang mewakili setiap rumah tangga yang terpilih. Sedangkan data sekunder diperoleh dari lembaga atau instansi yang terkait dalam penelitian ini. Pengambilan contoh dilakukan dengan metode multistages cluster random sampling dimana pemilihan contoh dilakukan dengan beberapa tahap secara acak karena sifat/karakteristik kelompok pada populasi cenderung heterogen.

Tahap pertama, rumah tangga yang akan diambil sebagai contoh adalah kecamatan Amuntai Selatan berdasarkan atas tingkat keragaman tingkat pendapatan, jenis pekerjaan, tingkat pendidikan, daerah asal, dan sebagainya. Tahap kedua, dari rumah tangga yang berada di kecamatan Amuntai Selatan tersebut terdapat 30 desa yang akan diambil 20\% secara acak rumah tangganya, dimana terpilih 6 desa yaitu Desa Kota Raja, Desa Jumba, Desa Murung Sari, Desa Mamar, Desa Teluk Paring dan Desa Cempaka. Tahap ketiga, Dari 6 desa yang terpilih diambil lagi secara acak yaitu Desa Jumba sebanyak 20 rumah tangga, Desa Murung Sari sebanyak 20 rumah tangga, Desa Mamar sebanyak 20 rumah tangga, Desa Teluk Paring sebanyak 20 rumah tangga, Desa Cempaka sebanyak 20 rumah rumah tangga, Desa Mamar sebanyak 20 rumah tangga, Desa Teluk Paring sebanyak 20 rumah tangga, Desa Cempaka sebanyak 20 rumah tangga dan Desa Kota Raja diambil sebanyak 50 rumah tangga karena jumlah rumah tangga yang lebih banyak dibandingkan Desa yang lain.

\section{Hipotesis}

1. Terdapat hubungan antara tingkat permintaan bawang merah dengan pendapatan, harga, jumlah anggota keluarga, pendidikan formal Ibu rumah tangga dan umur Ibu rumah tangga.

2. Terdapat hubungan antara tingkat permintaan bawang merah dengan daerah asal Ibu rumah tangga dan selera Ibu rumah tangga.

\section{Analisis Data}

Untuk mengetahui besarnya jumlah permintaan rumah tangga terhadap bawang merah dan untuk mengetahui besarnya 
Arief Hidayatullah \& Riswandi, Faktor sosial ekonomi yang berhubungan...

pengeluaran rumah tangga untuk bawang merah dilakukan dengan analisis tabulasi.

Untuk menyatakan hubungan pengaruh faktor sosial ekonomi terhadap besarnya permintaan bawang merah dengan variabel pendapatan keluarga, harga bawang merah, jumlah anggota keluarga, umur Ibu rumah tangga, tingkat pendidikan formal Ibu rumah tangga, umur Ibu rumah tangga, daerah asal Ibu rumah tangga dan selera Ibu rumah tangga digunakan analisis korelasi dengan rumus (Muhidin dan Abdurahman, 2007):

$$
\mathrm{r}=\frac{\sum \mathrm{xy}}{\sqrt{\sum \mathrm{x} 2 \sum \mathrm{y}^{2}}}
$$

Pengujian hopotesis untuk keterkaitan hubungan antara variabel-variabel tersebut digunakan Uji-t dengan rumus :

$$
\mathrm{t}_{\text {hit }}=\frac{(\mathrm{n}-2)}{\sqrt[r]{1-\mathrm{r}^{2}}}
$$

Dimana :

- $\mathrm{H}_{0}$ diterima jika $\mathrm{t}-\mathrm{hit} \leq \mathrm{t} \alpha / 2$; (n-2) : Terdapat hubungan yang tidak berarti antara variabel bebas dengan variabel tergantung

- $\mathrm{H}_{0}$ ditolak jika $\mathrm{t}$ - hit hit > $\mathrm{t} \alpha / 2$; $(\mathrm{n}-2)$ : Terdapat hubungan yang berarti antara variabel bebas dengan variabel tergantung

Secara manual untuk mendeteksi saling keterkaitan antara Faktor Sosial Ekonomi dengan Tingkat Konsumsi digunakan konsep analisis lintasan dengan persamaan sebagai berikut:

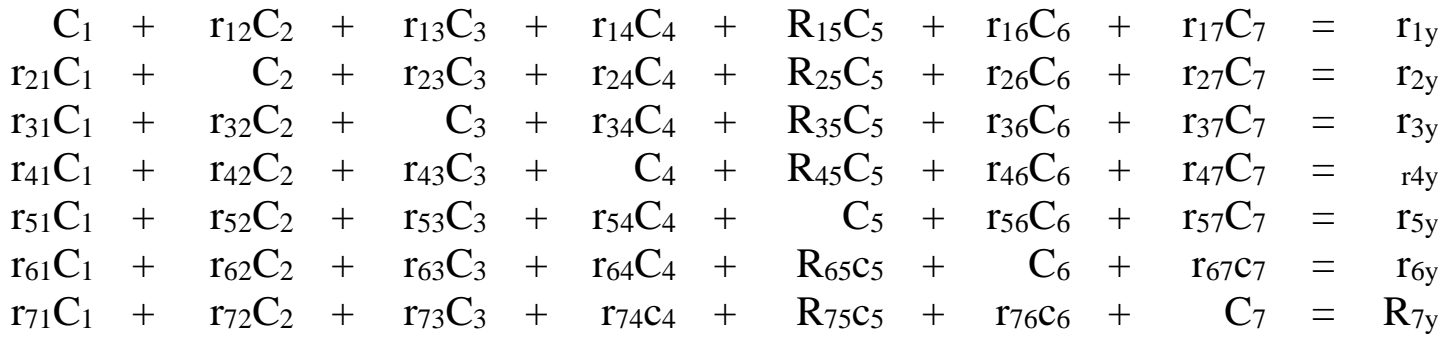

Sifat analisis korelasi adalah rii $=1$ dan $\mathrm{rij}=$ rji, untuk $i, j=1,2, \ldots \ldots, p$; dimana $p$ adalah banyaknya variabel dalam persamaan. Persamaan (4) memiliki makna bahwa hubungan antara variabel pendapatan dan permintaan bawang merah $(\mathrm{r} 1 \mathrm{y}=\mathrm{rx} 1 \mathrm{y})$ merupakan akumulasi dari pengaruh langsung pendapatan terhadap permintaan bawang merah (C1) dan pengaruh tidak langsung dari pendapatan melalui harga bawang merah, jumlah anggota keluarga, tingkat pendidikan, daerah asal Ibu rumah tangga terhadap permintaan bawang merah (r12C2, r13C3, r14C4, r15C5, r16C6, dan r17C7) demikian seterusnya. Sistem persamaan (4) dapat diubah dalam bentuk matrik sebagai berikut :

$$
\left(\begin{array}{lllllll}
1 & \mathrm{r}_{12} & \mathrm{r}_{13} & \mathrm{R}_{14} & \mathrm{r}_{15} & \mathrm{r}_{16} & \mathrm{r}_{17} \\
\mathrm{r}_{21} & 1 & \mathrm{r}_{23} & \mathrm{R}_{24} & \mathrm{r}_{25} & \mathrm{r}_{26} & \mathrm{r}_{27} \\
\mathrm{r}_{31} & \mathrm{r}_{32} & 1 & \mathrm{R}_{34} & \mathrm{r}_{35} & \mathrm{r}_{36} & \mathrm{r}_{37} \\
\mathrm{r}_{41} & \mathrm{r}_{42} & \mathrm{r}_{21} & 1 & \mathrm{r}_{21} & \mathrm{r}_{46} & \mathrm{r}_{47} \\
\mathrm{r}_{51} & \mathrm{r}_{52} & \mathrm{r}_{53} & \mathrm{R}_{54} & 1 & \mathrm{r}_{56} & \mathrm{r}_{57} \\
\mathrm{r}_{61} & \mathrm{r}_{62} & \mathrm{r}_{63} & \mathrm{R}_{64} & \mathrm{r}_{65} & 1 & \mathrm{r}_{67} \\
\mathrm{r}_{71} & \mathrm{r}_{72} & \mathrm{r}_{73} & \mathrm{R}_{74} & \mathrm{r}_{75} & \mathrm{r}_{76} & 1
\end{array}\right) \quad\left(\begin{array}{l}
\mathrm{C}_{1} \\
\mathrm{C}_{2} \\
\mathrm{C}_{3} \\
\mathrm{C}_{4} \\
\mathrm{C}_{5} \\
\mathrm{C}_{6} \\
\mathrm{C}_{7} \\
\mathrm{C}
\end{array}\right)=\left(\begin{array}{c}
\mathrm{r}_{1 \mathrm{y}} \\
\mathrm{r}_{2 \mathrm{y}} \\
\mathrm{r}_{3 \mathrm{y}} \\
\mathrm{r}_{4 \mathrm{y}} \\
\mathrm{r}_{5 \mathrm{y}} \\
\mathrm{r}_{6 \mathrm{y}} \\
\mathrm{R}_{7 \mathrm{y}} \\
\mathrm{Ry}
\end{array}\right)
$$


Rawa Sains: Jurnal Sains STIPER Amuntai, Desember 2011, 1(1), 24-29.

Dengan demikian permasalahan dalam analisis lintasan adalah menemukan besaranbesaran dari vektor $\underline{\mathrm{C}}$ karena dengan diketahuinya nilai-nilai $\mathrm{C} 1, \mathrm{C} 2, \mathrm{C} 3, \mathrm{C} 4, \mathrm{C} 5$, C6 dan $\mathrm{C} 7$, maka pengaruh langsung dan tidak langsung dari suatu faktor sosial ekonomi (variabel bebas) terhadap tingkat permintaan (variabel tak bebas) dapat ditentukan. Vektor $\underline{\mathrm{C}}$ dapat ditentukan sebagai berikut:

$$
\underline{\mathrm{C}}=\mathrm{R}_{\mathrm{x}}^{-1} \cdot \mathrm{R}_{\mathrm{y}}
$$

Selanjutnya untuk mengetahui koefisien lintasan dari setiap variabel penjelas, yang dapat langsung diperbandingkan untuk mengetahui peranan masing-masing variabel sosial ekonomi terhadap permintaan bawang merah, maka harus dihitung simpangan baku dari kata masing-masing variabel.

Kemudian dihitung pengaruh galat (sisaan) yang ditulis sebagai berikut(Gaspersz, 1991):

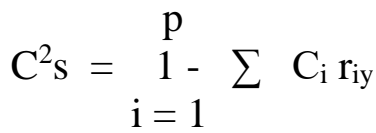

dimana :

$\mathrm{C}^{2} \mathrm{~S} \quad=$ pengaruh galat (sisaan)

$\mathrm{C}_{\mathrm{i}} \quad=$ koefesien lintasan ke-i

$\mathrm{r}_{\mathrm{iy}} \quad=$ koefesien korelasi antara variabel

bebas ke-i dengan varibel tak bebas

Setelah diketahui pengaruh yang sesungguhnya atau besarnya pengaruh dari masing-masing variabel sosial ekonomi terhadap variabel permintaan dan juga besarnya pengaruh langsung dan pengaruh tak langsung dari variabel-variabel tersebut, kemudian dibuat diagram lintasan untuk model fungsi permintaan dengan tujuh faktor sosial ekonomi tersebut.

Program yang digunakan pada penelitian ini adalah SPSS 13.0 for Windows. SPSS atau Statistical Product and Service
Solution merupakan program aplikasi untuk Windows yang digunakan untuk melakukan perhitungan statistik menggunakan komputer. SPSS mengalami perkembangan dari versi 6.0 hingga versi 11.0, 12.0 sampai yang terakhir 13.0. Kelebihan program ini adalah kita dapat melakukan secara lebih cepat semua perhitungan statistik dari yang sederhana sampai yang rumit sekalipun (Sarwono, 2006).

\section{HASIL DAN PEMBAHASAN}

\section{Jumlah Permintaan Bawang Merah}

Berdasarkan hasil penelitian, bahwa rata-rata jumlah permintaan bawang merah oleh masing-masing rumah tangga di Kecamatan Amuntai Selatan adalah 1,44 $\mathrm{kg} / \mathrm{bulan}$.

\section{Pendapatan dan Pengeluaran untuk Permintaan Bawang Merah}

Dari hasil analisis diperoleh bahwa besarnya pendapatan rata-rata keluarga responden adalah Rp. 1,593,333.34 per bulan, sedangkan pengeluran rata-rata untuk permintaan bawang merah adalah $\mathrm{Rp}$. $8,338.33$ per bulan. Ini berarti ratio antara pengeluaran untuk permintaan bawang merah terhadap pendapatan sebesar $0,52 \%$. Dengan kata lain bahwa kurang dari $10 \%$ pendapatan responden untuk membeli bawang merah.

\section{Permintaan Bawang Merah yang Berhubungan dengan Faktor Sosial Ekonomi}

Tabel berikut ini menunjukkan hubungan antara tingkat permintaan dengan faktor sosial ekonomi yang diduga berhubungan atau berkorelasi.

\begin{tabular}{|c|c|c|c|c|c|c|c|c|}
\hline & $\mathbf{Y}$ & X1 & X2 & X3 & X4 & X5 & X6 & $\mathbf{X 7}$ \\
\hline $\mathbf{Y}$ & 1,000 & 0,171 & 0,061 & 0,706 & 0,222 & 0,014 & 0,068 & 0,651 \\
\hline X1 & & 1,000 & 0,458 & $-0,141$ & 0,684 & -0110 & 0,216 & 0,371 \\
\hline $\mathrm{X} 2$ & & & 1,000 &,- 0103 & 0,529 & $-0,077$ & 0,254 & 0,210 \\
\hline $\mathrm{X3}$ & & & & 1,000 & $-0,082$ &, 077 &, 033 &, 277 \\
\hline $\mathrm{X} 4$ & & & & & 1,000 &,- 0147 & ,205 &, 359 \\
\hline X5 & & & & & & 1,000 & $-0,007$ & ,082 \\
\hline X6 & & & & & & & 1,000 &, 065 \\
\hline X7 & & & & & & & & 1,000 \\
\hline
\end{tabular}

Tabel 1. Hubungan antara Tingkat Permintaan Bawang Merah dengan Faktor Sosial Ekonomi 


\section{Hubungan dan Pengaruh Pendapatan terhadap Tingkat Permintaan Bawang Merah}

Berdasarkan koefisien Uji-t , diperoleh angka $\mathrm{t}$ penelitian sebesar $0,507<\mathrm{t}$ tabel sebesar 1,980 maka $\mathrm{H}_{0}$ diterima dan $\mathrm{H}_{1}$ ditolak. Artinya, tidak ada hubungan linear antara permintaan bawang merah dengan pendapatan dan besarnya pengaruh pendapatan terhadap permintaan bawang merah adalah 0,031 atau 3,1\%.

Korelasi sebesar 0,171 mempunyai maksud hubungan antara variabel pendapatan dan permintaan sangat lemah dan searah (karena hasilnya positif). Hal ini berarti bahwa dengan meningkatnya pendapatan keluarga maka hanya ada sedikit kecenderungan akan meningkatkan jumlah permintaan bawang merah.

\section{Hubungan dan Pengaruh Harga terhadap Tingkat Permintaan Bawang Merah}

Berdasarkan uji $\mathrm{T}$ diperoleh angka $\mathrm{t}$ penelitian sebesar $-0,895<\mathrm{t}$ tabel sebesar 1,980 maka $\mathrm{H}_{0}$ diterima dan $\mathrm{H}_{1}$ ditolak. Artinya, tidak ada hubungan linear antara permintaan bawang merah dengan harga dan besarnya pengaruh harga terhadap permintaan bawang merah adalah sebesar 0,047 atau $4,7 \%$.

Korelasi sebesar 0,061 mempunyai maksud hubungan antara variabel harga dengan permintaan sangat lemah dan searah (karena hasilnya positif). Hal ini berarti bahwa dengan meningkatnya harga bawang merah, tidak berarti akan menurunkan jumlah permintaan bawang merah oleh konsumen dan kalaupun permintaan bawang merah meningkat hanya ada sedikit peningkatan. Tetapi menurut hukum permintaan pada dasarnya semakin tinggi harga maka akan menurunkan permintaan, namun hal ini dapat di jelaskan karena waktu diadakan penelitian kenaikan harga bawang merah masih stabil.

\section{Hubungan dan Pengaruh Jumlah Anggota Keluarga terhadap Tingkat Permintaan Bawang Merah}

Berdasarkan uji $\mathrm{T}$ diperoleh angka $\mathrm{t}$ penelitian sebesar $12,674>\mathrm{t}$ tabel sebesar 1,980 maka $\mathrm{H}_{0}$ ditolak dan $\mathrm{H}_{1}$ diterima. Artinya ada hubungan linear antara permintaan bawang merah dengan jumlah anggota keluarga dan besarnya pengaruh Jumlah Anggota Keluarga terhadap permintaan bawang merah adalah sebesar 0,593 atau $59,3 \%$.

Korelasi sebesar 0,706 mempunyai maksud hubungan antara variabel jumlah anggota keluarga dengan permintaan kuat dan searah (karena hasilnya positif). Hal ini berarti dengan bertambahnya jumlah anggota keluarga maka akan meningkatkan jumlah permintaan bawang merah dalam rumah tangga.

\section{Hubungan dan Pengaruh Pendidikan terhadap Tingkat Permintaan Bawang Merah}

Berdasarkan uji $\mathrm{T}$ diperoleh angka $\mathrm{t}$ penelitian sebesar 1,617 < t tabel sebesar 1,980 maka $\mathrm{H}_{0}$ diterima dan $\mathrm{H}_{1}$ ditolak. Artinya tidak ada hubungan linear antara permintaan bawang merah dengan pendidikan. Besarnya pengaruh pendidikan terhadap permintaan bawang merah sebesar 0,103 atau $10,3 \%$.

Korelasi 0,222 mempunyai maksud hubungan antara variabel Pendidikan dengan permintaan sangat lemah dan searah (karena hasilnya fositif). Hal ini berarti konsumen yang mempunyai tingkat pendidikan yang tinggi maka ada sedikit kecenderungan akan meningkatkan jumlah permintaan bawang merah.

\section{Hubungan dan Pengaruh Umur terhadap Tingkat Permintaan Bawang Merah}

Berdasarkan Uji $\mathrm{T}$ diperoleh angka $\mathrm{t}$ penelitian sebesar $-1,228<\mathrm{t}$ tabel sebesar 1,980 maka $\mathrm{H}_{0}$ diterima dan $\mathrm{H}_{1}$ ditolak. Artinya tidak ada hubungan linear antara tingkat permintaan bawang merah dengan umur ibu rumah tangga. Besarnya pengaruh umur ibu rumah tangga terhadap permintaan bawang merah adalah $-0,054$ atau $5,4 \%$.

Korelasi sebesar 0,014 mempunyai maksud hubungan antara variabel umur dengan permintaan sangat lemah dan searah. Hal ini berarti bertambahnya umur ibu rumah tangga tidak begitu berarti akan meningkatkan permintaan bawang merah, karena dilihat dari kolerasinya hanya ada 
Rawa Sains: Jurnal Sains STIPER Amuntai, Desember 2011, 1(1), 24-29.

sedikit kecenderungan akan meningkatkan permintaan bawang merah.

\section{Hubungan dan Pengaruh Daerah Asal terhadap Tingkat Permintaan Bawang Merah}

Berdasarkan uji $\mathrm{T}$ diperoleh angka $\mathrm{t}$ penelitian sebesar $0,055<\mathrm{t}$ tabel sebesar 1,980 maka $\mathrm{H}_{0}$ diterima dan $\mathrm{H}_{1}$ ditolak. Artinya tidak ada hubungan linear antara tingkat permintaan bawang merah dengan daerah asal ibu rumah tangga. Besarnya pengaruh asal daerah ibu rumah tangga terhadap permintaan bawang merah adalah 0,002 atau $0,2 \%$.

Korelasi sebesar 0,068 mempunyai maksud hubungan antara variabel daerah asal dengan permintaan sangat lemah dan searah. Hal ini berarti bahwa daerah asal ibu rumah tangga, tidak berarti akan ada kecenderungan meningkatkan jumlah permintaan bawang merah.

\section{Pengaruh Selera terhadap Tingkat Permintaan Bawang Merah}

Berdasarkan uji $\mathrm{T}$ diperoleh angka $\mathrm{t}$ penelitian sebesar 8,925 > t tabel sebesar 1,980 maka H0 ditolak dan $\mathrm{H} 1$ diterima. Artinya ada hubungan linear antara tingkat permintaan bawang merah dengan selera ibu rumah tangga. Besarnya pengaruh selera ibu rumah tangga terhadap permintaan bawang merah adalah 0,453 atau 4,53\%.

Korelasi sebesar 0,651 mempunyai maksud hubungan antara variabel daerah asal dengan permintaan kuat dan searah. Hal ini berarti konsumen yang mempunyai tingkat selera yang tinggi akan meningkatkan permintaan bawang merah.

\section{KESIMPULAN}

Besarnya permintaan bawang merah oleh masyarakat di Kecamatan Amuntai Selatan adalah rata-rata $1,44 \mathrm{~kg} / \mathrm{bulan}$ dan besarnya pengeluaran untuk permintaan bawang merah di Kecamatan Amuntai Selatan adalah Rp. 8,338.33 per bulan atau sebesar $0,52 \%$ dari rata-rata pendapatan keluarga.

Terdapat hubungan yang signifikan antara tingkat permintaan bawang merah dengan jumlah anggota keluarga dan selera ibu rumah tangga, sedangkan faktor pendapatan keluarga, harga bawang merah, tingkat pendidikan formal ibu rumah tangga, umur ibu rumah tangga dan daerah asal ibu rumah tangga tidak mempunyai hubungan yang signifikan terhadap permintaan bawang merah.

\section{DAFTAR PUSTAKA}

Gaspersz Vincent. 1991. Ekonometrika Terapan 2. Tarsito. Bandung.

Muhidin, SA dan Maman Abdurahman. 2007. Analisis Kolerasi, Regresi dan Jalur dalam Penelitian. CV Pustaka Setia. Bandung.

Rahayu Estu dan Nur Berlian, V. A. 2004. Mengenal Varietas Unggul Dan Cara Budidaya Secara Kontinu.

Sarwono, J. 2006. Analisis Data Penelitian Menggunakan SPSS. Penerbit Andi. Yogyakarta.

Samadi Budi dan Bambang Cahyono. 2005. Bawang Merah. Penerbit Kanisius. Yogyakarta. 